\title{
Late Holocene climate variability in the southwestern Mediterranean region: an integrated marine and terrestrial geochemical approach
}

\author{
C. Martín-Puertas ${ }^{1}$, F. Jiménez-Espejo ${ }^{2}$, F. Martínez-Ruiz ${ }^{2}$, V. Nieto-Moreno ${ }^{2}$, M. Rodrigo $^{2}$, M. P. Mata ${ }^{3}$, and \\ B. L. Valero-Garcés ${ }^{4}$ \\ ${ }^{1}$ German Research Center for Geosciences (GFZ), Telegrafenberg, 14473 Potsdam, Germany \\ ${ }^{2}$ Facultad de Ciencias, Instituto Andaluz de Ciencias de la Tierra, Consejo Superior de Investigaciones Científicas \\ (CSIC)-Univ. de Granada, Campus Fuentenueva, 18002 Granada, Spain \\ ${ }^{3}$ Instituto Geológico y Minero de España, Área de cambio global, C/ La Calera, 28760, Tres Cantos, Madrid, Spain \\ ${ }^{4}$ Instituto Pirenaico de Ecología, Consejo Superior de Investigaciones Científicas (CSIC). Apdo 13034, 50080, \\ Zaragoza, Spain
}

Received: 20 August 2010 - Published in Clim. Past Discuss.: 6 September 2010

Revised: 6 December 2010 - Accepted: 13 December 2010 - Published: 15 December 2010

\begin{abstract}
A combination of marine (Alboran Sea cores, ODP 976 and TTR $300 \mathrm{G}$ ) and terrestrial (Zoñar Lake, Andalucia, Spain) geochemical proxies provides a highresolution reconstruction of climate variability and human influence in the southwestern Mediterranean region for the last 4000 years at inter-centennial resolution. Proxies respond to changes in precipitation rather than temperature alone. Our combined terrestrial and marine archive documents a succession of dry and wet periods coherent with the North Atlantic climate signal. A dry period occurred prior to $2.7 \mathrm{cal} \mathrm{kaBP}$ - synchronously to the global aridity crisis of the third-millennium $\mathrm{BC}$ - and during the Medieval Climate Anomaly (1.4-0.7 cal ka BP). Wetter conditions prevailed from 2.7 to $1.4 \mathrm{cal} \mathrm{ka} B \mathrm{BP}$. Hydrological signatures during the Little Ice Age are highly variable but consistent with more humidity than the Medieval Climate Anomaly. Additionally, $\mathrm{Pb}$ anomalies in sediments at the end of the Bronze Age suggest anthropogenic pollution earlier than the Roman Empire development in the Iberian Peninsula. The Late Holocene climate evolution of the in the study area confirms the see-saw pattern between the eastern and western Mediterranean regions and the higher influence of the North Atlantic dynamics in the western Mediterranean.
\end{abstract}

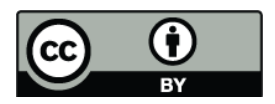

Correspondence to: C. Martín-Puertas (celia@gfz-potsdam.de)

\section{Introduction}

The southwestern Mediterranean region is an area of great interest for paleoclimate research, characterized by the interaction of the northern Africa subtropical and the midlatitude North Atlantic climate systems. Both influences have controlled climate variability since the onset of the modern Mediterranean climate after the mid Holocene and helped to create the unique environmental conditions that determine the landscape, biota and human societies evolution in this area.

Geochemical archives encoded in marine and lacustrine sediments offer clues for reconstructing the environmental processes and past climate changes. In paleoceanography, geochemical proxies describe most of the processes occurring in the ocean such as paleoproductivity (e.g., MartínezRuiz et al., 2003), deepwater ventilation (e.g, Mangini et al., 2001) and paleotemperatures (e.g., Toyofuku et al., 2000; Cacho et al., 2006). In lakes, geochemical data have unraveled the atmospheric pollution (e.g. Renberg et al., 2001; Ruiz-Fernández et al., 2007) and paleoenvironmental (e.g. Koinig et al., 2003; Eusterhues et al., 2005; Selig et al., 2007) and paleoclimate evolution (e.g. Moreno et al., 2007; Tanaka et al., 2007; Brauer et al., 2008; Giralt et al., 2008; Czymzik et al., 2010; Martín-Puertas et al., 2009). The rapid response of lakes to changes in the environmental conditions together with relatively high sedimentation rates favor the preservation of high-resolution geochemical signals (Battarbee, 2000). Nevertheless, reconstructing environmental

Published by Copernicus Publications on behalf of the European Geosciences Union. 
and climate proxies from geochemical lake records should be done carefully, since each lake is unique, controlled to some extent by its geographic and geological setting and the interactions among external chemical inputs and internal biogeochemical cycles (Cohen, 2003).

In the southwestern Mediterranean region, several paleoclimate studies focused on abrupt climate changes since the Last Glacial Maximum have been carried out using geochemical proxies from marine sediments, (e.g., MartínezRuiz et al., 2003; Moreno et al., 2005; Sierro et al., 2005; Cacho et al., 2006; Jiménez-Espejo et al., 2008). However, Late Holocene high-resolution records are still scarce. In this article, we combine geochemical information from marine records in the southwestern Mediterranean Sea (Alboran Sea) and lacustrine records from the southwestern Iberian Peninsula. The Alboran record provides evidences of changes in the hydrographic conditions and the sea surface temperature and the lacustrine record shows hydrological fluctuations in the continent and the possible traces of human impact. The aim of this study is to obtain a more accurate reconstruction of the Late Holocene climate change dynamics in the southwestern Mediterranean region using geochemical proxies from both marine and terrestrial environments.

\section{Regional setting}

The southwestern Mediterranean region comprises the westernmost basin of the Mediterranean Sea, called the Alboran Sea, and the South of the Iberian Peninsula and the North of Morocco (Fig. 1). This area is characterized by semi-humid Mediterranean climate with warm and dry summers and mild and wet winters. The Alboran Sea receives terrigenous sediments from both African and European continents as atmospheric dust and coastal/riverine inputs (e.g. Martínez-Ruiz et al., 2003). Controlled by the same climate, Zoñar Lake is one of the few permanent, relatively deep $(\mathrm{Z} \max =14 \mathrm{~m})$ lakes in southern Spain $\left(37^{\circ} 29^{\prime} 00^{\prime \prime} \mathrm{N}, 4^{\circ} 41^{\prime} 22^{\prime \prime} \mathrm{W}, 300 \mathrm{~m}\right.$ a.s.l.) (Fig. 1). Its hydrological balance is highly sensitive to the precipitation regime (Valero-Garcés et al., 2006) and sediment cores have provided a continuous, high-resolution Late Holocene record (Martín-Puertas et al., 2008).

\section{Materials and methods}

Two marine cores from the Alboran Sea basin and a terrestrial core from Zoñar Lake (Fig. 1) have been selected for this study. The maximum distance between the marine and terrestrial sites is about $300 \mathrm{~km}$. The marine records selected are: the ODP Site $976 \mathrm{C}-1 \mathrm{H}$ in the West Alboran Sea basin, located at $36^{\circ} 12^{\prime} \mathrm{N}, 4^{\circ} 18^{\prime} \mathrm{W}, 1108 \mathrm{~m}$ b.s.l.; and Site TTR $300 \mathrm{G}$ at $36^{\circ} 52^{\prime} 55^{\prime \prime} \mathrm{N}, 2^{\circ} 17^{\prime} 25^{\prime \prime} \mathrm{W}$ drilled at $1860 \mathrm{~m}$ b.s.l in the East Alboran Sea basin (Fig. 1). Core ODP 976C-1H was recovered at Site 976 during the ODP,

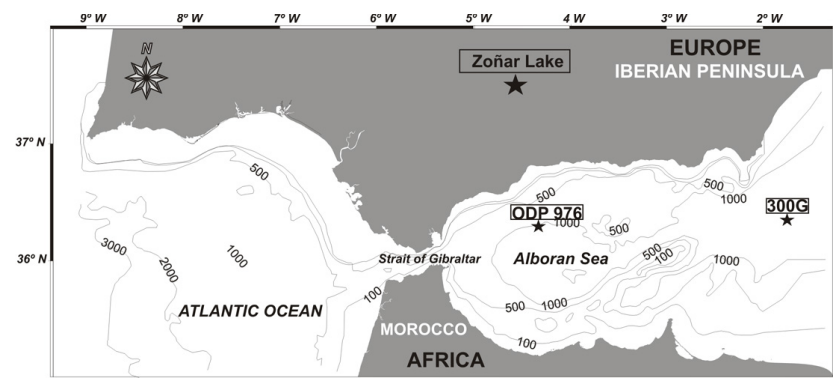

Fig. 1. Map of the continental and marine core sites.

Leg 161 in 1995 and core $300 \mathrm{G}$ during the Training Through Research (TTR) cruise 14, Leg 2 in 2004. Cores from Zoñar Lake were recovered with a Kullenberg corer in a joint Spanish - US Expedition in 2004. The composite lake record was obtained from correlation of four cores in the deepest area ( $14 \mathrm{~m}$ water depth, up to $6 \mathrm{~m}$ long) and one in the littoral zone (6m water depth, up to $3 \mathrm{~m}$ long) (see MartínPuertas et al., 2008). For the studied interval, marine cores ODP $976 \mathrm{C}-1 \mathrm{H}$ and $300 \mathrm{G}$ were sampled continuously at 2 and 1.5, respectively, and Zoñar core 1B was sampled every $10 \mathrm{~cm}$. Sediment samples were dried and homogenized in an agate mortar for subsequent geochemical analyses. Major elements were measured using Atomic Absorption Spectrometry (AAS) (Perkin-Elmer 5100 spectrometer) with an analytical error of $2 \%$. Analyses of trace elements were performed using Inductively Coupled Plasma-Mass Spectrometry (ICP-MS) following HNO3 + HF digestion. Measurements were taken in triplicates by spectrometry (PerkinElmer Sciex Elan 5000) using Re and Rh as internal standards. Variation coefficients determined by the dissolution of 10 replicates of powdered samples were higher than $3 \%$ and $8 \%$ for analyte concentrations of $50 \mathrm{ppm}$ and $5 \mathrm{ppm}$, respectively (Bea, 1996). Geochemical elements selected for this study $(\mathrm{Mg}, \mathrm{Sr}, \mathrm{Rb}, \mathrm{Zr}$ ) were normalized to $\mathrm{Al}$, since $\mathrm{Al}$ does not show fractionation and has very little ability to move during diagenesis (Calvert and Pedersen, 1992; Pipper and Perkins, 2004). Additionally, stable oxygen isotope ratio of monospecific planktonic foraminifers ( $G$. bulloides) from core $300 \mathrm{G}$ were also obtained. Foraminifers were cleaned in an ultrasonic bath to remove fine-fraction contamination, rinsed with distilled water, and thoroughly washed in alcohol. Stable isotopes were measured using a Finnigan MAT 251 mass spectrometer (Isotope Laboratory, Marum, University of Bremen, Germany). $\delta^{18} \mathrm{O}$ data are relative to the PDB standard. Analytical reproducibility of the method is approximately $+0.07 \%$ (see Jiménez-Espejo et al., 2008).

The Late Holocene age-depth model for the Alboran basin cores is based on six radiocarbon data from G. bulloides. The age model for the last $25000 \mathrm{yr}$ at Site ODP 976 is based on ten AMS radiocarbon ages performed on monospecific samples of Globigerina bullotdes and Neogloboquadrina pachyderma (Combourieu Nebout et al., 2009). In this core, 
the top $118 \mathrm{~cm}$ represent the last $4.0 \mathrm{cal} \mathrm{ka}$. In core $300 \mathrm{G}$ the age model for the last $13000 \mathrm{yr}$ is based on five radiocarbon data from G. bulloides and the last 4.0 cal ka extend the first $66 \mathrm{~cm}$ (Jiménez-Espejo et al., 2008). For Zoñar Lake core, the age-depth model for the last $4.0 \mathrm{cal} \mathrm{ka}$ is based on nine $\mathrm{AMS}^{14} \mathrm{C}$ dates, ${ }^{137} \mathrm{Cs}$ dating and varve counting (MartínPuertas et al., 2008). All radiocarbon ages for the marine core were calibrated to calendar years using Calib 5.1 software (Stuvier and Reimer, 1993) and the MARINE04 calibration curve including a standard marine correction of 400 years (Hughen et al., 2004). Continental data were calibrated using the INTCAL04 curve (Reimer et al., 2004).

\section{Paleoenvironmental and paleoclimate proxies}

\subsection{Alboran Sea}

A number of studies have shown how climate variability at global, regional and local scale modifies the hydrographic conditions of the Alboran Sea and influences its sedimentary dynamic (Sierro et al., 2005; Llave et al., 2006; Voelker et al., 2006). Terrigenous fraction of the Alboran sediments is the sum of atmospheric dust and eroded material transported by rivers from emerged areas. The first one is mainly related to the activity of the Saharan dust air masses reaching the studied area (Weldeab et al., 2003; Moreno et al., 2005 ) and is responsible for an enrichment of heavy minerals (rutile and zircon) in the sediments (Guieu and Thomas, 1996). The $\mathrm{Zr} / \mathrm{Al}$ ratio has been used as an indicator of the Sahara dust deposition in the western Mediterranean basin (Moreno et al., 2005). The second one, the fluvial input from the emerged areas, comes from both the African and Iberian margins in the southeastern of the Alboran Sea basin, but only from the Iberian margin in the northwest part. Sediments are composed of clay minerals, quartz, and minor amounts of feldspar, dolomite and other accessory minerals (Martínez-Ruiz et al., 2003). Mg enrichment (Mg/Al) is associated with increases in detrital input because the occurrence of Mg-rich chlorite and dolomite in the sediment is only from the Iberian margin (Jiménez-Espejo et al., 2008). Saharan winds are stronger during arid periods in the western Mediterranean region (Weldeab et al., 2003; Moreno et al., 2005), while coastal/riverine contribution from the continental margin has been mainly associated with increases in precipitation since the Last Glacial until the $5.0 \mathrm{ka} \mathrm{BP}$ (JiménezEspejo et al., 2008). Nevertheless, during some arid periods (e.g. the Younger Dryas), higher erosion and river incision were caused by a decrease in the vegetation cover rather than a rise in fluvial runoff (Jiménez-Espejo et al., 2008).

In order to discriminate the influence of riverine input on the $\mathrm{Mg}$ record, we have compared $\mathrm{Mg} / \mathrm{Al}$ ratio at Site ODP 976 - located close to the Iberian margin and significantly affected by fluvial discharges - with $\mathrm{Zr} / \mathrm{Al}$ ratio from core $300 \mathrm{G}$ - more sensitive to Saharan dust supply because of

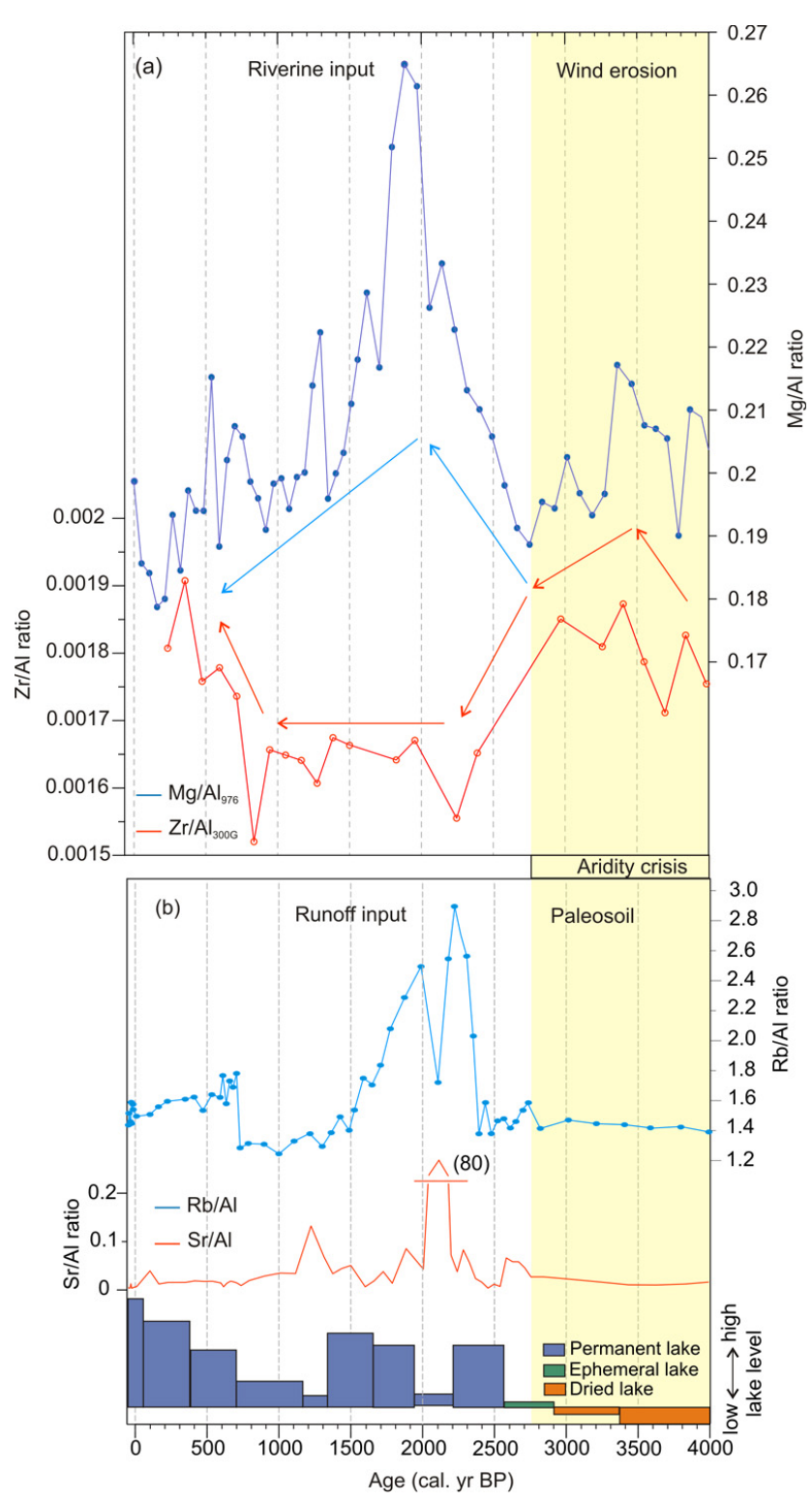

Fig. 2. (a) Alboran paleoenvironmental proxies: in blue, $\mathrm{Mg} / \mathrm{Al}$ ratio from core ODP976 sediments as indicator of Iberian riverine inputs into the Alboran basin; in red, $\mathrm{Zr} / \mathrm{Al}$ ratio from core $300 \mathrm{G}$ as Saharan dust inflow. (b) Zoñar paleoenvironmental proxies: in blue, $\mathrm{Rb} / \mathrm{Al}$ ratio as detrital input into the lake; in red, $\mathrm{Sr} / \mathrm{Al}$ ratio as ion water concentration (Martín-Puertas et al., 2009); and lake level reconstruction from multiproxy analyses published in MartínPuertas et al. (2008).

its lower sedimentation rate (Zuñiga et al., 2008) (Fig. 2a). The $\mathrm{Zr} / \mathrm{Al}$ ratio suggests two phases of higher aeolian supply from the Sahara: prior to $2700 \mathrm{cal}$ yr BP and during the Little Ice Age (LIA). $\mathrm{Mg} / \mathrm{Al}$ and $\mathrm{Zr} / \mathrm{Al}$ ratios have similar trends between 4000 and $2750 \mathrm{cal}$ yr BP but they are opposite from 2750 cal yr BP to present day (Fig. 2a). Prior $2750 \mathrm{cal}$ yr BP, strengthened Saharan winds indicate an arid period with increased wind erosion in the African margin. 
Table 1. Geochemical proxies applied for this study from the Alboran Sea and Zoñar Lake sediments.

\begin{tabular}{lllll}
\hline Proxy & Source & Environmental process & Forcing variable & Validity (cal yr BP) \\
\hline $\mathrm{Mg} / \mathrm{Al}$ ratio & Alboran ODP976 & Fluvial runoff & Precipitation & 2700 to present \\
$\mathrm{Zr} / \mathrm{Al}$ ratio & Alboran 300 G & Saharan winds & Precipitation* & 4000 to present \\
$\delta^{18} \mathrm{O}$ & Alboran 300 G & Sea Surface Temperature & Temperature & 4000 to present \\
$\mathrm{Rb} / \mathrm{Al}$ ratio & Zoñar Lake & Runoff & Precipitation & 2600 to present \\
$\mathrm{Pb} / \mathrm{Al}$ ratio & Alboran 300 $\mathrm{G}$ & Lead pollution & Human impact & 4000 to present \\
& Zoñar Lake & & & \\
\hline
\end{tabular}

* Inverse relationship between the proxy and the variable.

Since $2750 \mathrm{cal}$ yr BP, lower $\mathrm{Zr} / \mathrm{Al}$ and higher $\mathrm{Mg} / \mathrm{Al}$ ratios would reflect riverine input, weaker Saharan winds and more humid conditions (Table 1).

Late Holocene $\delta^{18} \mathrm{O}$ shifts indicate decreases in sea surface temperature (SST) around $2-3{ }^{\circ} \mathrm{C}$ in the Western Mediterranean Sea (Cacho et al., 2001; Frigola et al., 2007, Jimenez-Espejo et al., 2008). The $\delta^{18} \mathrm{O}$ record in core $300 \mathrm{G}$ shows good correlation with these events (Fig. 4), as well as with other paleotemperature proxies (Cacho et al., 2001).

\subsection{Zoñar Lake}

The major lacustrine response to climate change in the Mediterranean areas is lake level fluctuations (Cohen, 2003). Water input to Zoñar Lake is the sum of rainfall, runoff, groundwater and springs; the output is mostly by evaporation. Instrumental data during the last 20 years show that lake level fluctuation responds rapidly to changes in the precipitation (Valero-Garcés et al., 2006). Thus, the lake hydrology is directly related to the precipitation/evaporation balance $(\mathrm{P} / \mathrm{E})$. Ion water concentration increased during phases of higher evaporation, causing aragonite and gypsum precipitation and, consequently, Sr-enrichment in sediments ( $\mathrm{Sr} / \mathrm{Al}$ ). However, this ratio cannot be used as an indicator of $\mathrm{P} / \mathrm{E}$ variability trough the whole Late Holocene since aragonite precipitation only represents extreme episodes of water concentration. Higher precipitation also means more watershed erosion by runoff and a higher detrital input into the lake (clay minerals, quartz, feldspar and detrital calcite). Geochemically, the allochthonous component of the sediments is characterized by $\mathrm{Al}, \mathrm{K}, \mathrm{Fe}, \mathrm{Si}, \mathrm{Ca}, \mathrm{Rb}$ and other associated trace elements (Martín-Puertas et al., 2009). Based on the statistical treatment carried out by these authors, we propose $\mathrm{Rb}$ as possible proxy for watershed erosion. $\mathrm{Rb}$ has been normalized to $\mathrm{Al}$ in order to discriminate changes in the relative contribution from different terrigenous sources. Principal Component and Redundancy Analyses (PCA and RDA) (Martín-Puertas et al., 2009) show that Rb is associated with clay minerals and controlled by the first eigenvector, which distinguishes between detrital and endogenic. Al also represents the allochthonous component of the sediments, but it is, together with magnetic susceptibility and quartz, pos- itively related to the third eigenvector. The third eigenvector indicates development of saline to brackish environments with reworking of exposed littoral sediments during lower lake level stages (Martín-Puertas et al., 2009). So, $\mathrm{Al}$ is also associated with this reworked material sedimentation favored during episodes of lower precipitation. In order to test the reliability of $\mathrm{Rb}$ as runoff proxy, we compare $\mathrm{Rb} / \mathrm{Al}$ ratio with $\mathrm{Sr} / \mathrm{Al}$ ratio (water concentration phases) and the semiquantitative lake level curve based on multiproxy-analyses (Martín-Puertas et al., 2008) (Fig. 2b). Prior 2900 cal yr BP, Zoñar Lake dried out and soil-forming processes occurred even in the deepest basin. The onset of lacustrine deposition started at 2900 cal yr BP with evaporitic facies (gypsum) and aragonite precipitation in an ephemeral lake (MartínPuertas et al., 2008, 2009). Zoñar Lake has been a permanent lake until present day. Phases of more intense evaporation ( $\mathrm{Sr} / \mathrm{Al}$ peaks) correspond with lower values of the $\mathrm{Rb} / \mathrm{Al}$ ratio (lower detrital input). Additionally, the general $\mathrm{Rb} / \mathrm{Al}$ trends are coherent with the most important lake level changes interpreted from the multiproxy analyses (Fig. 2b). So, we propose $\mathrm{Rb} / \mathrm{Al}$ ratio variability responds mostly to changes in runoff-precipitation during the last 2600 years (Table 1).

\section{Chronological markers and human influence}

To compare the marine and continental records at highresolution scales we should demonstrate the compatibility of both chronological models. As chronological markers, we have used the signatures of atmospheric lead pollution during the Roman Empire (2050-1750 cal yr BP) and Medieval Times (950-750 cal yr BP) defined for the North Atlantic region (Renberg et al., 2001). Figure 3 shows $\mathrm{Pb}$ enrichment in sediments ( $\mathrm{Pb} / \mathrm{Al}$ ratio) of the AlboranAlboran Sea and Zoñar Lake records: Roman lead pollution is recorded in both, but the Medieval signal only occurs in the AlboranAlboran Sea records. The radiocarbon data close to the $\mathrm{Pb}$-enrichment in the Alboran sediments supports the timing of lead pollution signature during Medieval Times. The absence of this enrichment in the Zoñar Lake sequence could be explained by the deposition of evaporitic facies and the occurrence of subaerial exposure episodes between 


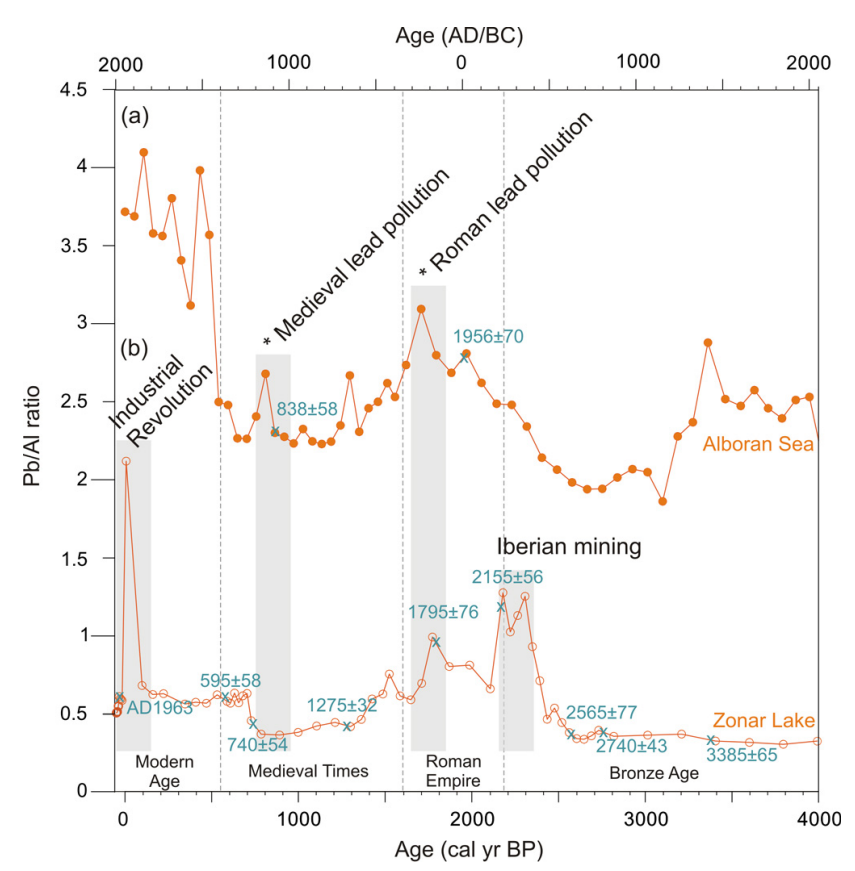

Fig. 3. $\mathrm{Pb} / \mathrm{Al}$ ratios from (a) the Alboran basin (core ODP976) and (b) Zoñar Lake. ${ }^{14} \mathrm{C}$ and ${ }^{137} \mathrm{Cs}$ data are included. Gray bars indicate lead pollution peaks.

1350 and 730 cal yr BP (Fig. 3) (Valero-Garcés et al., 2006, Martín-Puertas et al., 2008). In any case, the synchronous $\mathrm{Pb}$ peak during the Roman period would validate the comparison between both records and strengthen both chronological models.

Human activities can compromise the use of geochemical data as paleoclimate proxies, especially in continental records (Vannière et al., 2008). The watershed and the hydrological balance of Zoñar Lake have been directly affected by land uses and water management changes since the Bronze Age (Valero-Garcés et al., 2006 and MartínPuertas et al., 2008). The $\mathrm{Pb} / \mathrm{Al}$ peak in Zoñar Lake at 2300-2100 cal yr BP (350-150 BC) (Fig. 3) could indicate early lead contamination by runoff coinciding with the $\mathrm{Rb} / \mathrm{Al}$ peak at 2200 cal yr BP (Fig. 2b). That was a time of enhanced mining and smelting activity by the Iberian culture and increased trading with Greek and Phoenician societies (Rothenberg et al., 1989). During the Roman period (100 BC-AD300), human activities could have amplified the lake response to climate (Martín-Puertas et al., 2009) and both drier conditions and spring water diversion for human consumption would have been responsible for decreased lake level, increased chemical concentration and precipitation of gypsum during $2100-1700$ cal yr BP. Sedimentological profiles show massive facies indicating soil erosion during Medieval Times and from the onset of the industrial revolution (Valero-Garcés et al., 2006) (Fig. 3).

\section{Climate variability for the South Iberian Mediterranean region}

The Alboran and Zoñar records have robust chronological models and the geochemical proxies are not perturbed by human influence, so the marine and continental records can be used for reconstructing natural climate variability over the southwester Mediterranean region during the Late Holocene. Precipitation proxies $(\mathrm{Mg} / \mathrm{Al}$ and $\mathrm{Rb} / \mathrm{Al})$ correlate well at centennial to decadal scale (Fig. 4) and show a coherent trend with the $\mathrm{Zr} / \mathrm{Al}$ ratio demonstrating a common signal for moisture variability in the South of the Iberian Peninsula. Both records show more arid conditions from 4000 to 2700 cal yr BP: dry out and ephemeral lakes in Zoñar and higher Saharan input ( $\mathrm{Zr} / \mathrm{Al}$ ratio) in the Alboran record $(300 \mathrm{G})$. This arid period is consistent with the global aridity crisis in the third millennium BC (Weiss et al., 1993).

Since 2700 cal yr BP, $\mathrm{Mg} / \mathrm{Al}$ and $\mathrm{Rb} / \mathrm{Al}$ ratios reflect three phases of rainfall variability: $2.7-1.5 \mathrm{cal} \mathrm{ka} \mathrm{BP} ; 1.4-$ $0.7 \mathrm{cal} \mathrm{ka} \mathrm{BP}$; and the last 700 years. General trend of $\mathrm{Mg} / \mathrm{Al}$, $\mathrm{Rb} / \mathrm{Al}$ and $\mathrm{Zr} / \mathrm{Al}$ ratios suggest a progressive humidity recovery from 2700 to $2500 \mathrm{cal} \mathrm{yr} \mathrm{BP}$. The most humid episode occurred at $\sim 2500-1700$ cal yr BP, characterized by weaker winds from Africa (Fig. 4). Precipitation decreases from 1400 to $700 \mathrm{cal}$ yr BP coinciding with the Medieval Climate Anomaly (MCA). The end of MCA is marked by increase in the precipitation at 700-550 cal yr BP (AD 1250-1400) and cooling during the LIA (Fig. 4). After $500 \mathrm{cal} \mathrm{yr} \mathrm{BP} \mathrm{(AD}$ 1400) there are discrepancies between the marine and continental hydrological signal. In the Alboran Sea, there is a clear decrease of coastal/riverine input. In Zoñar Lake, runoff also slightly decreases after AD 1400, but sedimentological, palinological and geochemical evidences show the LIA was wetter than the MCA (Valero-Garcés et al., 2006; Martín-Puertas et al., 2009). Other Iberian (Moreno et al., 2008; Benito et al., 2010; Morellón et al., 2009) and Moroccan (Esper et al., 2007) records show that the LIA was wetter than the MCA, in agreement with the Zoñar record. These discrepancies would suggest that core ODP 976C-1H age model is not sufficiently well constrained for the last $500 \mathrm{yr}$.

\section{South Iberian Mediterranean Archive and its connection with the Northern Hemisphere climate changes.}

As we have shown above, our geochemical proxies for Alboran and Zoñar are mostly driven by changes in precipitation, and, consequently, they are adequate to reconstruct changes in the Mediterranean area where during the last three millennia, humid conditions have been related to cooling phases in the northern-central Europe and the Mediterranean region (Magny, 2004; Mauquoy et al., 2008). The timing of lower SST in the Alboran Sea fit generally well with both cool pulses in the western Mediterranean (Frigola et al., 2007) 


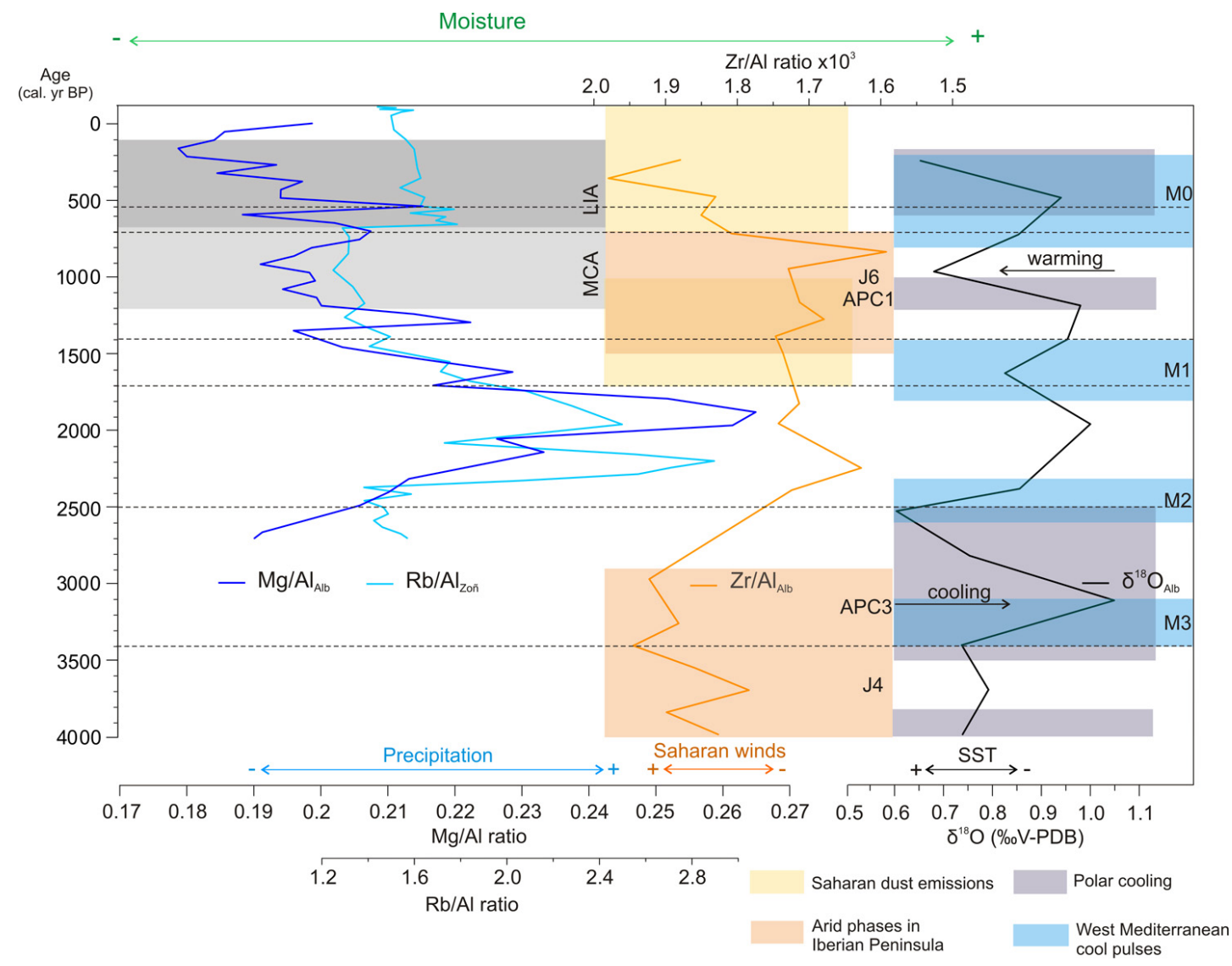

Fig. 4. Marine and continental geochemical proxies for climate variability: $\mathrm{Rb} / \mathrm{Al}$ ratio from Zoñar Lake sediments and $\mathrm{Mg} / \mathrm{Al}$ ratio from the Alboran Sea sediments reflect precipitation; $\mathrm{Zr} / \mathrm{Al}$ ratio indicates Saharan winds; $\delta^{18} \mathrm{O}$ is a proxy for Sea Surface Temperature (SST). Climatic events defined for the western Mediterranean region during the Late Holocene are included for comparison: Alboran Sea pollen events from core ODP 976 (APC1 and APC3) (Combourieu-Nebout et al., 2009), aridification phases in the western Mediterranean (J4 and J6) (Jalut et al., 2000), polar cooling (Mawyesky et al., 2004) and central Mediterranean cold pulses (M0 to 3) (Frigola et al., 2007).

and global polar cooling phases described by Mayewski et al. (2004) (Fig. 4). However there are some disagreements, in the associations of cool/wet and warm/dry conditions between global and regional events. The most humid period recorded during the Late Holocene (2.5-1.7 cal ka BP) coincides with two cool pulses for the western Mediterranean M2 and M1 - (Frigola et al., 2007) and also lower SST for the Alboran Sea (Fig. 4). This period is related to the cool and wet pulse around $2.8 \mathrm{cal} \mathrm{kaBP}$ in the North Atlantic region (Bond et al., 2001; van Geel et al., 1999), e.g.: northern Europe (Bond and Lotti, 1995), Greendland (Stuvier et al., 1995), western-central Europe (Magny, 2004), Demark (Mauquoy et al., 2008), The Netherland (van Geel et al., 1996) and the northwestern region of Spain (Bernárdez et al., 2008). On the other hand, the global cool and dry periods during 3.4-2.7 cal ka BP and 1.2-1.0 cal ka BP (Mayewski et al., 2004) also have a clear reflection in the western Mediterranean. Pollen data from the Iberian Peninsula (Jalut et al., 2000) and marine core ODP 976C-1H (Combourieu Nebout et al., 2009) suggest aridity prior $3000 \mathrm{cal} \mathrm{yr} \mathrm{BP}$ and during the MCA coinciding with lower reconstructed precipitation in our records (Fig. 4). Arid conditions in southwestern Mediterranean region are in concordance with central Europe (Magny, 2004) (Fig. 5b). The onset of the last cool episode the LIA - (600-200 cal yr BP) is characterized in both Alboran and Zoñar records by an increase in precipitation, but it is followed by a slight decrease also identified in central Europe (Magny, 2004). Nevertheless, several archives point to more humid conditions during the LIA in the central-western Europe - higher lake level (Magny et al., 2007) (Fig. 5b, green bars) - and the northwest Europe - peat bog developments (Mauquoy et al., 2008); glacial advances (Nesje et al., 2008) - and other records from the Iberian Peninsula show a complex rainfall patter (Moreno et al., 2008; Morellón et al., 2009). All these records illustrate a different hydrological response in the western regions of the European continent during the LIA. 


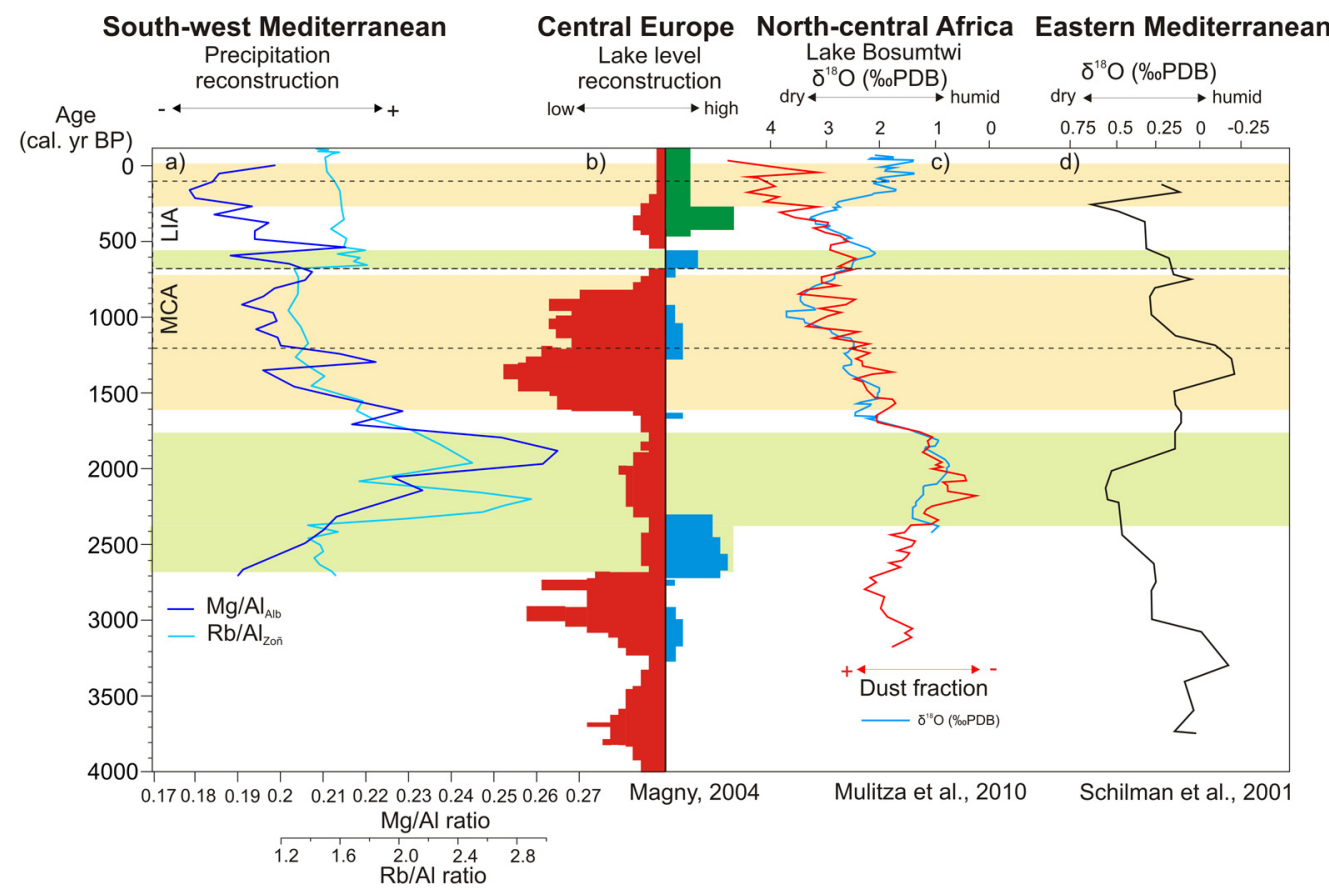

Fig. 5. Precipitation proxies ( $\mathrm{Rb} / \mathrm{Al}$ and $\mathrm{Mg} / \mathrm{Al}$ ratios) compared with lake level reconstruction for central Europe (Magny, 2004 in blue and red; Magny et al., 2007 in green), $\delta^{18} \mathrm{O}$ composition from Lake Bosumtwi (Mulitza et al., 2010) and South East Mediterranean Sea (Schilman et al., 2001) as indicators of humid conditions in North-central Africa and eastern Mediterranean, respectively.

The Late Holocene record of Sahara dust flux in the westcentral Africa (Mulitza et al., 2010) shows weaker Sahara dust emissions, more fluvial deposits and humid conditions during 3150-1750 cal yr BP, a trend towards increasing aridity after $1000 \mathrm{cal}$ yr BP, and a humidity recovery for the last 700 years. Similarly, increasing Saharan dust is also recorded in the Alboran basin during the last 700 years (Fig. 5c).

Interestingly, the Late Holocene climate variability over the eastern Mediterranean shows an opposite humidity pattern (Fig. 5d): wet periods from 3500 to $3000 \mathrm{cal} \mathrm{yr} \mathrm{BP}$ and 1700 to $1000 \mathrm{cal} \mathrm{yr} \mathrm{BP}$ and arid periods from 3000-1700 cal yr BP and 800-270 cal yr BP. Several archives demonstrate that the MCA was relatively humid in the eastern Mediterranean (Schilman et al., 2001; Wick et al., 2003; Jones et al., 2005, 2006; Neumann et al., 2007), while the LIA records shows regional variability with humid conditions in some records (Issar, 1998; Dragoni, 1998) an increase aridity in others (Bar-Matthews et al., 1998).

The regional comparison among the southwestern Mediterranean, west-central Europe, West Africa and the eastern Mediterranean regions suggests that Late Holocene moisture variability in the study area is more influenced by the North Atlantic dynamics (mid-latitude storm tracks modulated by the North Atlantic Oscillation). Moreover, the differences in the precipitation pattern between the western and eastern Mediterranean support the see-saw effect described by several authors during the Holocene (Rimbu et al., 2004; Roberts et al., 2008; Felis and Rimbu, 2010; Touchan et al., 2010).

\section{Conclusions}

The geochemical composition of sediments from the Alboran Sea and Zoñar Lake is a reliable proxy record for humidity fluctuations in the South Iberian Mediterranean region during the Late Holocene. The robust chronological control of both marine and continental sequence allows a reconstruction at centennial to decadal scales since $2700 \mathrm{cal}$ yr BP. Four main stages for the Late Holocene have been identified in the region: (i) an arid period prior $2.7 \mathrm{cal} \mathrm{ka} \mathrm{BP}$, (ii) a moisture recovery and the most humid conditions for the 2.51.7 cal ka BP period, (iii) a gradual decrease in precipitation and driest conditions during the MCA (1.4-0.7 cal ka BP) and (iv) more humid conditions with large hydrological variability during the last 700 years. The Late Holocene climate evolution in the southwestern Mediterranean region correlates better with the western-central Europe and West tropical Africa than the eastern Mediterranean and supports the seesaw climate pattern for the Mediterranean region during the Holocene. Additionally, evidences of $\mathrm{Pb}$-enrichment in sediments from the terrestrial record during the Late Bronze Age suggest early anthropogenic pollution.

Acknowledgements. Projects LIMNOCLIBER REN 2003-09130C02-02, CALIBRE CGL 2006-13327-c04/CLI, CGL-2006-2956BOS, CGL2009-07603 (MICINN), 200800050084447 (MARM) and RNM 05212 (Junta de Andalucía), we also thanks Projects GRACCIE (CSD2007- 00067) and CTM2009-07715 (MICINN), Research Group 0179 (Junta de Andalucía) and the TrainingThrough-Research Programme. We thank the LRC (University 
of Minnesota, USA) and particularly to Doug Schnuremberger, Mark Shapley and Anders Noren for making possible the 2004 Zoñar expedition. Celia Martín-Puertas is grateful to Alexander von Humboldt Foundation. Finally, the editor Nerilie Abram and two anonymous reviewers provided constructive criticisms and suggestions.

Edited by: N. Abram

\section{References}

Bar-Matthews, M., Ayalon, A., and Kaufman, A.: Middle to late Holocene (6500 years period) paleoclimate in the eastern Mediterranean region from stable isotopic composition of speleothems from Soreq Cave, Israel, in: Water, Environments and Society in times of Climate Change, edited by: Issar, A. S. and Brown, N., Kluwer Academic Publisher, 203-214, 1998.

Battarbee, R. W.: Paleolimnological approaches to climate change, with special regard to the biological record, Quaternary. Sci. Rev., 19, 107-124, 2000.

Bea, F.: Residence of REE, Y, Th and U in granites and crustal protoliths: implications for the chemistry of crustal melts, J. Petrol., 37, 521-552, 1996.

Benito, G., Rico, M., Sánchez-Moya, Y., Sopeña, A., Thorndycraft, V. R., and Barriendos, M.: The impact of late Holocene climatic variability and land use change on the flood hydrology of the Guadalentín River, southeast Spain, Global. Planet. Change., 70, 53-63, 2010.

Bernárdez, P., González-Álvarez, R., Francés, G., Prego, R., Bárcena, M. A., and Romero, O. E.: Late Holocene history of the rainfall in the NW Iberian peninsula-Evidence from a marine record, J. Mar. Syst., 72, 366-382, 2008.

Bond, G., Kromer, B., Beer, J., Muscheler, R., Evans, M. N., Showers, W., Hoffmann, S., Lotti-Bond, R., Hajdas, I., and Bonani, G.: Persistent solar influence on North Atlantic climate during the Holocene, Science, 294, 2130-2136, 2001.

Bond, G. and Lotti, R.: Iceberg discharges into the North Atlantic on millennial time scales during the last glaciation, Science, 267 , 1005-1010, 1995.

Brauer, A., Haug, G. H., Dulski, P., Sigman, M., and Negendank, J. F. W.: An abrupt wind shift in western Europe at the onset of the Younger Dryas cold period, Nat. Geosci., 1(8), 520-523, doi:10.1038/ngeo263, 2008.

Calvert S. E. and Pedersen T. F.: Organic carbon accumulation and preservation in marine sediments: how important is anoxia?, in: productivity, accumulation and preservation of organic matter in recent and ancient sediments, edited by: Whelan, J. K. and Farrington, J. W., Columbia University Press, New York, 231-263, 1992

Cacho, I., Grimalt, O., Canals, M., Sbaffi, L., Shackleton, J., Schonfeld, J., and Zahn, R.: Variability of the Western Mediterranean sea-surface temperature during the last 25000 years and its connection with the Northern-Hemisphere cli-matic changes, Paleoceanography, 16, 40-52, doi:10.1029/2000PA000502, 2001.

Cacho, I., Shackleton, N., Elderfield, H., Sierro, F. J., and Grimalt, J. O.: Glacial rapid variability in deep-water temperature and $\mathrm{d} 18 \mathrm{O}$ from the Western Mediterranean Sea, Quaternary. Sci. Rev., 25, 3294-3311, 2006.
Cohen, A. S.: Paleolimnology. The history and evolution of lake systems, Oxford University Press, New York, 2003.

Combourieu Nebout, N., Peyron, O., Dormoy, I., Desprat, S., Beaudouin, C., Kotthoff, U., and Marret, F.: Rapid climatic variability in the west Mediterranean during the last 25000 years from high resolution pollen data, Clim. Past, 5, 503-521, doi:10.5194/cp5-503-2009, 2009.

Czymzik, M., Dulski, P., Plessen, B., von Grafenstein, U., Nanmann, R., and Brauer, A.: A 450-years record of spring/summer flood layers in annually laminated sediments from Lake Ammersee (Southern Germany), Water. Resour. Res., 46, W11528, doi:10.1029/2009WR008360, in press, 2010.

Dragoni, W.: Some considerations on climatic changes, water resources and water needs in the Italian region south of $43^{\circ} \mathrm{N}$, in: Water, Environment and Society in Times of Climate Change, edited by: Issar, A. S. and Brown, N., Kluwer Academic Publishers, 241-271, 1998.

Esper, J., Frank, D., Büntgen, U., Verstege, A., Luterbacher, J., and Xoplaki, E.: Long-term drought severity variations in Morocco, Geophys. Res. Lett., 27, L17702, doi:10.1029/2007GL030844, 2007.

Eusterhues, K., Heinrichs, H., and Schneider, J.: Geochemical response on redox fluctuations in Holocene lake sediments, Lake Steisslingen, Southern Germany, Chem. Geol., 222, 1-22, 2005.

Felis, T. and Rimbu, N.: Mediterranean climate variability documented in oxygen isotope records from northern Red Sea coralsA review, Global. Planet. Change., 71, 232-241, 2010.

Frigola, J., Moreno, A., Cacho, I., Canals, M., Sierro, F. J., Flores, J. A., Grimalt, J. O., Hodell, D. A., and Curtis, J. H. Holocene climate variability in the western Mediterranean region from a deepwater sediment record, Paleoceanography, 22, PA2209, doi:10.1029/2006PA001307, 2007.

Giralt, S., Moreno, A., Bao, R., Sáez, A., Prego, R., Valero-Garcés, B. L., Pueyo, J. J., González-Sampériz, P., and Taberner, C.: A statistical approach to disentagle environmental forcing in a lacustrine record: the Lago Chungará case (Chilean Altiplano), J. Paleolimnol., 40, 195-215, 2008.

Guieu, C. and Thomas, A.: Saharan aerosol: from the soil to the Ocean, in: The impact of desert dust across the Mediterranean, edited by: Guerzoni, S. and Chester, R., Kluwer Academy Publishers, 207-216, 1996.

Hughen, K. A., Baillie, M. G. L., Bard, E., Bayliss, A., Beck, J. W., Bertrand, C. J. H., Blackwell, P. G., Buck, C. E., Burr, G. S., Cutler, K. B., Damon, P. E., Edwards, R. L., Fairbanks, R. G., Friedrich, M., Guilderson, T. P., Hogg, A. G., Kromer, B., McCormac, G., Manning, S., Bronk Ramsey, C., Reimer, P. J., Reimer, R. W., Remmele, S., Southon, J. R., Stuiver, M., Talamo, S., Taylor, F. W., van der Plicht, J., and Weyhenmeyer, C. E.: Marine04 Marine Radiocarbon Age Calibration, 0-26 ka cal BP, Radiocarbon, 46, 1059-1086, 2004.

Issar, A. S.: Climate change and history during the Holocene in the eastern Mediterranean region, in: Water, Environment Society in Times of Climate Change, edited by: Issar, A. S. and Brown, N., Kluwer Academic Publishers, 113-128, 1998.

Jalut, G., Esteban Amat, A., Bonnet, L., Gauquelin, T., and Fontugne, M.: Holocene climatic changes in the Western Mediterranean, from south-east France to south-east Spain, Palaeogeogr. Palaeocl., 160, 255-290, 2000.

Jiménez-Espejo, F. J., Martínez-Ruiz, F., Rogerson, M., González- 
Donoso, J. M., Romero, O., Linares, D., Sakamoto, T., GallegoTorres, D., Rueda Ruiz, J. L., Ortega-Huertas, M., and Perez Claros, J. A.: Detrital input, productivity fluctuations, and water mass circulation in the westernmost Mediterranean Sea since the Last Glacial Maximum, Geochem. Geophy. Geosy., 9, Q11U02, doi:10.1029/2008GC002096, 2008.

Jones, M. D., Leng, M. J., Roberts, N., Türkeş, M., and Moyeed, R.: A coupled calibration and modelling approach to the understanding of dry-land lake oxygen isotope records, J. Paleolimnol., 34, 391-411, 2005.

Jones, M. D., Roberts, N., Leng, M. J., and Türkeş, M.: A highresolution late Holocene lake isotope record from Turkey and links to North Atlantic and monsoon climate, Geology, 34, 361364, 2006.

Koinig, K. A., Shotyk, W., Lotter, A. F., Ohlendorf, C., and Strum, M.: 9000 years of geochemical evolution of lithogenic major and trace elements in the sediment of an alpine lake-the role of climate, vegetation, and land-use history, J. Paleolimnol., 30, 307320, 2003.

Llave, E., Schönfeld, J., Hernández-Molina, F. J., Mulder, T., Somoza, L., Díaz Del Río, V., and Sánchez-Almazo, I.: Highresolution stratigraphy of the Mediterranean outflow contourite system in the Gulf of Cadiz during the late Pleistocene: the impact of Heinrich events, Mar. Geol., 227, 241-262, 2006.

Magny, M.: Holocene climate variability as reflected by midEuropean lake-level fluctuations and its probable impact on prehistoric human settlements, Quatern. Int., 113, 65-79, 2004.

Magny, M., de Beaulieu, J.-L., Drescher-Schneider, R., Vannière, B., Walter-Simonnet, A.-V., Miras, Y., Millet, L., Bossuet, G., Peyron, O., Brugiapaglia, E., and Leroux, A.: Holocene climate changes in the central Mediterranean as recorded by lake-level fluctuations at Lake Accesa (Tuscany, Italy), Quaternary. Sci. Rev., 26, 1736-1758, 2007.

Mangini, A., Jung, M., and Laukenmann, S.: What do we learn from peaks of uranium and of manganese in deep sea sediments?, Mar. Geol., 177, 63-78, 2001.

Martín-Puertas, C., Valero-Garcés, B. L., Mata, M. P., GonzálezSampériz, P., Bao, R., Moreno, A., and Stefanova, V.: Arid and humid phases in southern Spain during the last 4000 years: The Zoñar Lake record, Córdoba, Holocene, 18, 907-921, 2008.

Martín-Puertas, C., Valero-Garcés, B. L., Mata, M. P., Moreno, A., Giralt, S., Martínez-Ruiz, F., and Jiménez-Espejo, F.: Geochemical processes in a Mediterranean Lake: a high resolution study of the last 4000 years in Zoñar Lake, southern Spain, J. Paleolimnol., 1-17, doi:10.1007/s10933-009-9373-0, 2009, in press, 2009.

Martínez-Ruiz, F., Paytan, A., Kastner, M., Gonzalez-Donoso, J. M., Linares, D., Bernasconi, S. M., and Jiménez-Espejo, F. J.: A comparative study of the geochemical and mineralogical characteristics of the S1 sapropel in the western and eastern Mediterranean, Palaeogeogr. Palaeocl., 190, 23-37, 2003.

Mauquoy, D., Yeloff, D., van Geel, B., Charman, D. J., and Blundell, A.: Two decadally resolved records from north-west European peat bolgs show rapid climate changes associated with solar variability during the mid-late Holocene, J. Quaternary. Sci., 23, 745-763, 2008.

Mayewski, P. A., Rohling, E. E., Stager, J. C., Karlén, W., Maasch, K. A., Meeker, L. D., Meyerson, E. A., Gasse, F., van Kreveld, S., Holmgren, K., Lee-Thorp, J., Rosqvist, G., Rack, F., Staub- wasser, M., Schneider, R. R., and Steig, E. J.: Holocene climate variability, Quaternary. Res., 62, 243-55, 2004.

Morellón, M., Valero-Garces, B. L., González-Samperiz, P., VegasVillarúbia, T., Rubio, E., Rieradevall, M., Delgado-Huertas, A., Mata, P., Romero, O., Engstrom, D. R., López-Vicente, M., Navas, A., and Soto, J.: Climate changes and human impact recorded in the sediments of Lake Estanya (NE Spain) during the Medieval Warm Period and Little Ice Age, J. Paleolimnol., 1-30, doi:10.1007/s10933-009-9346-3, in press, 2009.

Moreno, A., Cacho, I., Canals, M., Grimalt, J. O., Sánchez-Goñi, M. F., Shackleton, N., and Sierro, F. J.: Links between marine and atmospheric processes oscillating on a millennial timescale. A multi-proxy study of the last $50000 \mathrm{yr}$ from the Alboran Sea (Western Mediterranean Sea), Quaternary land-ocean correlation, Quaternary. Sci. Rev., 24, 1623-1636, 2005.

Moreno, A., Giralt, S., Valero-Garce's, B. L., Sa'ez, A., Bao, R., Prego, R., Pueyo, J. J., and Taberner, C.: A 14 ka record of the tropical Andes: The Lago Chungara' sequence $\left(18^{\circ} \mathrm{S}\right.$, northern Chilean Altiplano), Quatern. Int., 161, 4-21, 2007.

Moreno, A., Valero-Garcés, B. L., González-Sampériz, P., and Rico, M.: Flood response to rainfall variability during the last 2000 years inferred from the Taravilla Lake record (Central Iberian Range, Spain), J. Paleolimnol., 40, 943-961, 2008.

Mulitza, S., Heslop, D., Pittauerova, D., Fischer, H. W., Meyer, I., Stuut, J. B., Zabe, M., Mollenhauser, G., Collins, J. A., Kuhnert, H., and Schulz, M.: Increase in African dust flux at the onset of commercial agriculture in the Sahel region, Nature, 466, 226228, doi:10.1038/nature09213, 2010.

Nesje, A., Dahl, S. O., Thun, T., and Nordli, Ø.: The 'Little Ice Age'glacial expansion in western Scandinavia: summer temperature or winter precipitation?, Clim. Dynam., 30, 789-801, 2008.

Neumann, F. H., Kagan, E. J., Schwab, M. J., and Stein, M.: Palynology, sedimentology and palaeoecology of the late Holocene Dead Sea, Quaternary. Sci. Rev., 26, 1476-1498, 2007.

Piper, D. Z. and Perkins, R. B.: A modern vs Permian black shale the hydrography, primary productivity, and water-column chemistry of deposition, Chem. Geol., 206, 177-197, 2004.

Reimer, P. J., Baillie, M. G, Bard, E., Beck, J. W., Buck, C. E., Blackwell, P. G., Burr, G. S., Cutler, K. B., Damon, P. E., Edwards, R. L., Fairbanks, R. G., Friedrich, M., Guilderson, T. P., Hogg, A. G., Hughen, K. A., Kromer, B., McCormac, G., Ramsey, C. B., Reimer, R. W., Remmele, S., Southon, J. R., Stuvier, M., Taylor, F. W., van der Plicht, J., and Weyhenmeyer, C. E.: IntCal04: A New Consensus Radiocarbon Calibration Dataset from 0-26 ka BP, Radiocarbon, 46, 1029-1058, 2004.

Renberg, I., Bindler, R., and Brännvall, M. L.: Using the historical atmospheric lead-deposition record as a chronological marker in sediment deposits in Europe, Holocene, 11, 511-516, 2001.

Rimbu, N., Dima, M., Lohmann, G., and Stefan, S.: Impacts of the North Atlantic Oscillation and the El Niño-Southern Oscillation on Danube river flow variability, Geophys. Res. Lett., 31, 1-4, 2004.

Roberts, N., Jones, M. D., Benkaddour, A., Eastwood, W. J., Filippi, M. L., Frogley, M. R., Lamb, H. F., Leng, M. J., Reed, J. M., Stein, M., Stevens, L., Valero-Garces, B., and Zanchetta, G.: Stable isotope record of Late Quaternary climate and hydrology from Mediterranean lakes: the ISOMED synthesis, Quaternary. Sci. Rev., 27, 2426-2441, 2008.

Rothenberg, B., Garcia Palomero, F., Bachmann, H. G., and 
Goethe, J. W.: Mineria y metalurgia en las antiquas civilizaciones mediterraneas y europeas, in: Madrid, edited by: Domergue, I. C., Tomo, 1, 57-70, 1989.

Ruiz-Fernández, A. C., Páez-Osuna, F., Urrutia-Fucugauchi, J., and Preda, M.: ${ }^{210} \mathrm{~Pb}$ geochronology of sediment accumulation rates in Mexico City Metropolitan Zone as recorded at Espejo de los Lirios lake sediments, Catena, 61, 31-48, 2007.

Selig, U., Leipe, T., and Dörfler, W.: Paleolimnological Record of nutrient and metal profile in prehistoric, historic and modern sediments of three lakes in north-eastern Germany, Water. Air. Soil. Poll., 184, 183-194, 2007

Sierro, F. J., Hodell, D. A., Curtis, J. H., Flores, J. A., Reguera, I., Colmenero-Hidalgo, E., Bárcena, M. A., Grimalt, J. O., Cacho, I., Frigola, J., and Canals, M.: Impact of iceberg melting on Mediterranean thermohaline circulation during Heinrich events, Paleoceanography, 20, 1-13, 2005.

Schilman, B., Bar-Matthews, M., Almogi-Labin, A., and Luz., B.: Global climate instability reflected by Eastern Mediterranean marine records during the Late Holocene, Palaeogeog. Palaeocl., 176, 157-176, 2001.

Stuvier, M. and Reimer, P. J.: Extended ${ }^{14} \mathrm{C}$ data base and revised CALIB 3.0. ${ }^{14} \mathrm{C}$ Age calibration program, Radiocarbon, 35, 215230, 1993.

Stuvier, M., Grottes, P. M., and Braziunas, T. F.: The GISP2 160 climate record of the past 16500 years and the role of the sun, ocean, and volcanoes, Quaternary. Res., 44, 341-354, 1995.

Tanaka, K., Akagawa, F., Yamamote, K., Tani, Y., Kawabe, I., and Kawai, T.: Rare Earth Elements geochemistry of Lake Baikal sediment: its implication for geochemical response to climate change during the Last Glacial/Interglacial transition, Quaternary. Sci. Rev., 26, 1362-1368, 2007.

Toyofuku, T., Kitazato, H., Kawahata, H., Tsuchiya, M., and Nohara, M.: Evaluation of $\mathrm{Mg} / \mathrm{Ca}$ thermometry in foraminifera: Comparison of experimental results and measurements in nature, Paleoceanography, 15, 456-464, 2000.

Touchan, R., Anchukaitis, K. J., Meko, D. M., Sabir, M., Attalah, S., and Aloui, A.: Spatiotemporal drought variability in northwestern Africa over the last nine centuries, Clim. Dynam., 1-16, doi:10.1007/s00382-010-0804-4, 2010.
Valero-Garcés, B. L., González-Sampériz, P., Navas, A., Machín, J., Mata, P., Delgado-Huertas, A., Bao, R., Moreno, A., Carrión, J. S., Schwalb, A., and González-Barrios, A.: Human impact since medieval times and recent ecological restoration in a Mediterranean lake: The Laguna Zoñar, southern Spain, J. Paleolimnol., 35, 441-465, 2006.

Vannière, B., Colombaroli, D., Chapron, E., Leroux, A., Tinner, W., and Magny, M.: Climate versus human-driven fire regimes in Mediterranean landscapes: the Holocene record of Lago dell'Accesa (Tuscany, Italy), Quaternary. Sci. Rev., 27, 11811196, 2008.

van Geel, B., Buurman, J., and Waterbolk, H. T.: Archaelogical and palaeoecological indications of an abrupt climate change in the Netherlands, and evidence for climatological teleconnections around 2650 BP, J. Quaternary. Sci., 11, 451-460, 1996.

van Geel, B., Raspopov, O. M., Renssen, H., Van der Plicht, J., Dergachev, V. A., and Meijer, H. A. J.: The role of solar forcing upon climate change, Quaternary. Sci. Rev., 18, 331-338, 1999.

Voelker, A. H. L., Lebreiro, S. M., Schönfeld, J., Cacho, I., Erlenkeuser, H., and Abrantes, F.: Mediterranean outflow strengthening during Northern Hemisphere coolings: a salt source for the glacial Atlantic?, Earth. Planet. Sc. Lett., 245, 39-55, 2006.

Weiss, H., Courty, M.-A., Wetterstrom, W., Guichard, F., Senior, L., Meadow, R., and Curnow, A.: The genesis and collapse of third millennium north mesopotamian civilization, Science 261, 995-1004, 1993.

Weldeab, S., Siebel, W., Wehausen, R., Emeis, K.-C., Schmiedl, G., and Hemleben, C.: Late Pleistocene sedimentation in the Western Mediterranean Sea: implications for productivity changes and climatic conditions in the catchment areas, Palaeogeogr. Palaeocl., 190, 121-137, 2003.

Wick, L., Lemcke, G., and Sturm, M.: Evidence of Lateglacial and Holocene climatic change and human impact in eastern Anatolia: high-resolution pollen, charcoal, isotopic and geochemical records from the laminated sediments of Lake Van, Turkey, Holocene, 13, 665-675, 2003.

Zúñiga, D., Calafat, A., Heussner, S., Miserocchi, S., SanchezVidal, A., Garcia-Orellana, J., Canals, M., Sánchez-Cabeza, J.A., Carbonne, J., Delsaut, N., and Saragoni, G.: Compositional and temporal evolution of particle fluxes in the open Algero-Balearic basin (Western Mediterranean), J. Marine. Syst., 70, 196-214, 2008. 